\title{
MEETING DATES
}

This list is limited to recurring regional and national meetings in which we feel MLA members will be interested. Suggestions for additions are welcome.

American Association of Teachers of French. 28, 29, and 30 December 1964, Hotel New Yorker, New York City.

American Association of Teachers of German. 27-30 December 1964, Sheraton Atlantic, New York City.

American Association of Teachers of Italian. 27 December 1964, Hotel New Yorker, New York City.

American Association of Teachers of Slavic and East European Languages. 27-29 December 1964, Hotel New Yorker, New York City.

American Association of Teachers of Spanish and Portuguese. 28-30 December 1964, Hotel New Yorker, New York City.

American Council of Learned Societies. 21-23 January 1965, Carnegie Endowment International Center, 345 E. 46th St., New York City.

American Dialect Society. 27 December 1964, Statler Hilton, New York City.

American Folklore Society. 27-29 December 1964, Park-Sheraton, New York City.

American Name Society. 29 and 30 December 1964, Statler Hilton, New York City.

American Philological Association. 28-30 December 1964, Sheraton-Biltmore, Providence, R. I.

American Studies Association. 28 December 1964, Statler Hilton, New York City.

Association for Asian Studies. 2-4 April 1965, Sheraton Palace, San Francisco.

Association of American University Presses. 23-25 May 1965, Univ. of Kentucky, Lexington.

Bibliographical Society of America. Dates not received in time for printing.

Central States Modern Language Teachers Association. 7-8 May 1965, Statler Hilton, St. Louis, Mo.

College Language Association. 22-24 April 1965, Greensboro, N.C.

Conference on College Composition and Communication. 8-10 April 1965, Jefferson Hotel, St. Louis.

English Institute. 8-11 September 1964, Columbia University, New York City.

Georgetown Roundtable (Institute of Languages and Linguistics). Dates not received in time for printing.
Indiana Language Conference. 11-13 March 1965 Indiana Memorial Union, Bloomington, Ind.

Kentucky Foreign Language Conference. 22-24 April 1965, Univ. of Kentucky, Lexington.

Linguistic Society of America. 27-30 December 1964, Roosevelt Hotel, New York City.

Mediaeval Academy of America. April 1965, Providence, R.I.

Middle States Association of Modern Language Teachers. 4-5 December 1964, ChalfonteHaddon Hall, Atlantic City, N.J.

Midwest Modern Language Association. 6-8 May 1965, Univ. of Chicago.

Modern Language Association. 27-29 December 1964, Statler Hilton and Sheraton Atlantic, New York City.

National Association of Foreign Student Affairs. Dates not received in time for printing.

National Council of Teachers of English. 26-28 November 1964, Cleveland, Ohio.

National Federation of Modern Language Teachers Associations. 28 December 1964, New York City.

New England Modern Language Association. Dates not received in time for printing.

New Jersey Modern Language Teachers Association. 13-14 November 1964, Dennis Hotel, Atlantic City; 13 March 1965, Montclair State Coll.; and 8 May 1965, Rutgers Univ., New Brunswick.

New York State Federation of Foreign Language Teachers. 9-10 October 1964, Syracuse, N.Y.

Northeast Conference on the Teaching of Foreign Languages. 9 and 10 April 1965, Americana, New York City.

Pacific Northwest Conference on Foreign Languages. Dates not received in time for printing.

Pennsylvania State Modern Language Association. 10 October 1964, Bucknell Univ., Lewisburg.

Philological Association of the Pacific Coast. 26 and 27 November 1964, Stanford University.

Rocky Mountain Modern Language Association. 9-10 October 1964, Arizona State Univ., Tempe.

South Atlantic Modern Language Association. 1214 November 1964, Poinsette Hotel, Greenville, S.C.

South-Central Modern Language Association. 12 and 13 November 1964, Texas Technological Coll., Lubbock. 